\title{
Decomposition of Waste Shells Using Multi-Complex Microorganisms
}

\author{
GunWoong Bahng ${ }^{1,+\odot} \cdot$ Hyun Park ${ }^{2 \odot} \cdot$ Myung Hee Suh ${ }^{3 \oplus} \cdot$ Hany Hong ${ }^{3 \oplus}$ \\ 'Department of Mechanical Engineering, The State University of New York, Korea, Republic of Korea \\ ${ }^{2}$ Department of Biotechnology, Korea University, Republic of Korea \\ ${ }^{3}$ Research Center, Miracle-Ecobio, Ltd., Republic of Korea
}

(Received July 1, 2021; Revised August 5, 2021; Accepted August 17, 2021)

Objectives: Korea is a global aquatic product producer/consumer country, and shellfish including oysters are no exception. Oysters occupy the largest proportion as a single variety in the domestic aquaculture industry. The production volume reaches an average of more than 300,000 tons per year. The oyster shells left after harvesting oyster is reaching over 280,000 tons/yr. About $70 \%$ of these are recycled, but the remaining shells which are over 60,000 tons, causing serious environmental problems such as odor and water pollution. In order to solve this problem, some local governments investigated the possibility of applying microorganisms, but it was effective only to remove odors and it was not possible to decompose the oyster shell itself. In this study, an attempt was made to solve the problem of waste shell decomposition by using multi-complex microorganisms rather than microorganisms composed of a few species.

Methods: As a waste food extinction facility in Korea, the first certified Q mark equipment was used. After mixing oyster shells and food wastes in a 1:1 ratio, they were subjected to decomposition and extinction treatment at a high temperature of $80{ }^{\circ} \mathrm{C}$ using multi-complex microorganisms. Multi-complex microorganisms are composed of various soil microorganisms, including aerobic and anaerobic microorganisms. They are in an activated ecosystem by forming a symbiotic relationship to obtain a strong decomposition synergistic effect.

Results and Discussion: The composition of complex microorganisms was mainly Firmicutes at the beginning, but Proteobacteria accounted for a half after 29 hours from the start of the experiment, and after 77 hours, it was shifted to Firmicutes A. All-organic components were decomposed within 72 hours, and the shell was changed to a powder form, and the total weight was reduced to less than $10 \%$ of the input total weight. It was found that treatment for at least 48 hours was required to decompose organic components from food waste, and after the organic components were decomposed, oyster shells were transformed into fine particles. The main components of the particles were calcium carbonate, which was identified as Aragonite and Calcite.

Conclusions: Considering that the main component of the shell is calcium carbonate, and the temperature at which calcium carbonate is decomposed into quicklime and carbon dioxide is around $800{ }^{\circ} \mathrm{C}$, the result of weight loss of the shell is difficult to explain with the existing thermal decomposition mechanism. It is necessary to explore further a new possible mechanism of shell decomposition by complex microorganisms.

Keywords: Multi-complex Microorganisms, Oyster Shell, Decompose

The Korean text of this paper can be translated into multiple languages on the website of http://jksee.or.kr through Google Translator.

Corresponding author
E-mail: gwbahng@sunykorea.ac.kr
Tel: 032-626-1222
c 2021, Korean Society of Environmental Engineers
This is an Open Access article distributed under the terms of the Creative Commons Attribution Non-Commercial License (http://creativecommons.org/licenses/by-nc/4.0/) which permits unrestricted non-commercial use, distribution, and reproduction in any medium, provided the original work is properly cited. 


\title{
연구논문
}

\section{복합미생물을 이용한 폐패각 소멸 처리}

\author{
방건웅 ${ }^{1,+\odot \cdot ㅂ ㅏ ㄱ ~} \quad$ 현 $^{2 \odot} \cdot$ 서명희 $^{3 \odot} \cdot$ 홍한의 $^{3 \odot}$
}

${ }^{1}$ 한국뉴욕주립대학교 기계공학과

2고려대학교 생명공학부

${ }^{3}$ 미라클에코바이오(주)

목적 : 우리나라는 세계적인 수산물 생산/소비국가로서 굴을 포함한 조개류도 예외는 아니다. 굴은 국내 양식산업 에서 단일 품종으로는 가장 큰 비중을 차지한다. 생산량은 매년 평균 30 만 톤 이상이다. 문제는 굴을 채취한 다음 에 발생하는 굴 껍데기로서 28만 톤 이상에 이른다. 이 가운데 $70 \%$ 정도는 재활용되고 있으나 남는 껍데기가 6 만 톤 이상이 되어 악취, 수질 오염 등의 심각한 환경 문제를 유발하고 있다. 이 문제를 해결하기 위하여 일부 지자체 에서 미생물을 이용하는 방법을 검토하고 있으나 악취를 제거하는 수준에 머물고 있을 뿐 굴 껍데기 자체를 소멸 시키지 못하고 있다. 본 연구에서는 기존의 단일종 미생물이 아닌 복합미생물을 이용하여 굴 껍데기 소멸처리 문 제를 해결하고자 시도하였다.

방법: 국내에서 음식물류 폐기물 처리 장치로는 최초로 $\mathrm{Q}$ 마크를 받은 장비를 이용하였다. 굴 껍데기와 음식물류 폐기물을 $1: 1$ 로 혼합하여 투입한 다음에 복합미생물을 이용하여 $80{ }^{\circ} \mathrm{C}$ 의 높은 온도에서 분해 소멸 처리를 하였다. 복합미생물은 호기성 미생물 및 혐기성 미생물들을 포함하는 다양한 토양 미생물들이 하나의 활성화된 공생 관계 의 생태계를 이루도록 제조하여 강력한 분해 상승효과가 얻어지도록 하였다.

결과 및 토의: 실험 결과 음식물류 폐기물에서 오는 유기성분을 분해하려면 최소 48시간 이상 처리하여야 하는 것으로 나타났으며 유기성분이 분해된 다음 굴 껍질이 조각 형태로 남는 것으로 나타났다. 처리된 시료의 주 성분은 탄산칼슘으로서 아라고나이트와 캘사이트로 확인되었다. 복합미생물의 구성을 분석한 결과 초기에는 주로 Firmicutes 이었으나 실험 시작 29시간 후에는 Proteobacteria가 절반을 차지하였고, 77시간이 지나면서 Firmicutes $A$ 로 바뀌었다. 72 시간 만에 유기성 성분은 모두 분해되고 투입 중량 대비 $10 \%$ 이하로 감소되었다. 음식물쓰레기 중 유기성분을 분해하기 위해서는 최소 48 시간 이상의 처리가 필요하며, 유기성분이 분해된 후 굴 껍질이 미세한 입자로 변하는 것으로 나타났다. 입자의 주성분은 탄산칼슘으로서 아라고나이트와 방해석으로 확인되었다.

결론 : 패각의 주성분이 탄산칼슘이고 탄산칼슘이 생석회와 이산화탄소로 분해되는 온도가 약 $800{ }^{\circ} \mathrm{C}$ 임을 감안할 때, 패각의 중량 감소 결과는 기존의 열분해 기전으로 설명하기 어렵다. 복합미생물에 의한 새로운 패각 분해 기전 에 대한 탐색이 필요하다.

주제어: 복합미생물, 굴 껍데기, 소멸처리

\section{1. 서론}

굴은 국내 양식산업에서 단일 품종으로 가장 큰 비중을 차 지한다. 1990년대에 급격히 증가하기 시작한 굴 양식은 연간 1,600 억 원의 수익을 올리며, 수출 규모는 연평균 600 억 원에 이르고 있다. 약 2 만여 명이 생산·가공·유통에 종사하고 있어 일자리 창출에도 크게 기여하고 있다. 한국 농수산물식품 유 통공사의 보고서에 따르면 2018년도에는 전국 굴 생산량이 31 만 5,255 톤 이었으며 여기에서 28 만 3,730 톤의 굴 껍데기가 발생하였다. ${ }^{1)}$ 이 중 약 $70 \%$ 는 채묘용 종패, 패화석 비료, 사
료, 건축자재 원재료, 탈황 재료, 제철 원료, 공유수면 매립지 역 성토재 등으로 재활용되었으나 나머지는 방치되어 굴 껍데 기를 벗겨내는 박신장(剝身場) 주변의 해안가에 쌓이고 있 다. ${ }^{2)}$ 실제로 2018년도에는 이 양이 6만 6,170톤에 이르렀을 정도로 심각한 문제가 되고 있다. 해외에서는 탄산칼슘 원료, 도로포장, 매립재, 수로 정화용 등으로 활용하고 있으나잉양 식을 통해 생산하는 양이 많지 않기 때문에 국내에서와 같은 정도로 심각한 상황은 아니며 일부 지역에서는 오히려 종패로 사용하기에도 모자랄 정도이다. ${ }^{4)}$

방치된 굴 껍데기는 악취, 해충 번식, 침출수 방출, 경관 훼 
손 등의 환경 문제를 일으키며, 다음 해 생산한 굴을 처리하는 과정에서 발생하는 굴 껍데기 처리를 더욱 어렵게 만든다. ${ }^{5}$ 굴 껍데기 문제를 해결하고자 통영시는 자체적으로 방안을 검토한 후(), 지방행정 발전연구원에 의뢰해 '굴 껍데기 자원 화시설 구축 타당성 및 경제성 분석 조사'를 수행하였다. 지방 행정 발전연구원은 자원화 시설로서 탈황설비, 액상 소석회 제조설비, 토목·건축자재 제조설비를 검토하였다. ${ }^{7)}$ 그러나 어느 방법을 사용하여도 적자가 예상되며, 흑자가 예상되는 경우라도 수요처가 없다는 난관에 부딪치게 된다는 것이 결론 이었다. 예를 들어 연간 굴 껍데기 10 만 톤을 처리할 수 있는 탈황공장을 건립할 경우, 한해 36 억 원의 적자가 발생하는 것 으로 나타났는데 그 이유는 $900{ }^{\circ} \mathrm{C}$ 이상의 온도로 가열하는데 소요되는 연료비가 전체 지출경비의 절반 이상을 차지하기 때문이다. ${ }^{8)}$ 그럼에도 불구하고 적자 예상액이 굴 껍데기 처리 연간 예산 약 60 억 원보다 적기 때문에 통영시는 보고서의 내용에 따라 굴 껍데기를 혼합형(탈황 + 액상 소석회 + 건축 기자재) 방식으로 자원화하는 사업을 추진하기로 결정하였다. 이들 설비를 건설하기 위한 예산으로 2021 년부터 150 억 원을 투입할 예정이나 여전히 적자가 예상되므로 근본적인 해결책 이 되지 못한다. ${ }^{9)}$

현재 통계자료에 따르면 지난 2010년부터 10년간 누적된 굴 껍데기 방치량이 20 만 톤 이상에 이르는 것으로 추정되고 있으나 실제로는 이보다 훨씬 많을 것으로 짐작되고 있다. 예 를 들어 경남도는 통영·거제·고성 등 경남에만 2019년 9월 말 현재 굴 껍데기가 20 만 톤 가량 쌓여있다고 보고하였다. 문제가 이처럼 심각함에도 불구하고 방치된 굴 껍데기를 폐 기할 방도가 없어서 톤당 6 만원 씩 모두 120 억 원을 들여 울산 남동쪽 동해정 해역에 버리는 방안을 추진하고 있다. ${ }^{10}$ 그러나 해양 투기는 또 다른 해양 오염을 불러올 수 있다는 우려와 함께 굴 껍데기가 폐기물관리법에서는 사업장 일반폐 기물(51-17-04, 동식물성 잔재물)로 분류되어 있어 이를 추진 하는 것도 어려운 상황이다. ${ }^{11,12)}$ 이와 같이 굴 껍데기 처리 문제가 심각한 상황이므로 굴 껍데기 산지 근처에서 저렴한 비용으로 처리가 가능하면서도 2 차 오염이 유발되지 않는 근 본적인 해결책이 필요하다.

지금까지 제안된 굴 껍데기 자원화 방안들을 살펴보면 굴 껍데기의 주성분인 탄산칼슘에 주목하였음을 알 수 있다. 그 러나 탄산칼슘을 재활용하고자 소석회로 만들려면 고열 분해 과정이 필요하므로 경제성을 충족시키기 어렵다는 문제가 있 다. 가장 바람직한 처리 방법은 경제성이 충족되면서도 짧은 시간 안에 소멸 처리하는 것이다. 저자들은 굴 껍데기가 층 상조직으로 되어 있으며 그 사이사이에 단백질의 일종인 콘 키올린(conchiolin) 층이 있다는 사실에 주목하였다. 단백질은 미생물의 먹이가 될 수 있으며 단백질 층이 분해되면 탄산칼 슘 층이 쉽게 분리될 것으로 예상할 수 있다.

그러나 미생물을 이용한 굴 껍데기 처리 방법에 대한 현황
을 살펴보면 굴 작업장에서 발생하는 악취를 제거하는 데 그 치고 있다. ${ }^{11)}$ 굴 껍데기에 부착된 유기물들과 굴 껍질 사이의 단백질만으로는 미생물들이 생존, 증식하기에 부족할 수 있으 므로 저자들은 굴 작업장 주변에서 쉽게 구할 수 있는 음식물 류 폐기물과 폐패각을 혼합하여 동시에 처리하는 방안을 검토 하였다. 미생물을 이용하여 굴 껍질을 처리할 경우, 특히 고려 해야 할 사항은 경제성의 측면에서 처리 속도가 높아야 한다 는 점이다. 이를 높이기 위한 방안으로서 고온 처리를 전제로 하였다. 그러나 $80{ }^{\circ} \mathrm{C}$ 이상의 고온에서는 미생물들의 생존력 이 문제가 될 수 있으므로 단일 미생물이 아니라 다양한 미생 물들이 상생 관계의 생태계를 이루는 복합미생물을 제조하여 실험을 수행하였다. 혐기성 미생물과 호기성 미생물을 포함 하는 여러 가지 미생물들이 복합적으로 공존하는 생태계가 이루어지면 단일 미생물에 비해 생존력이 높아지고 대사 기능 이 우수해진다는 사실은 미생물을 이용한 방사성 폐기물 처리 실험에서 확인되고 있다. 예를 들어 Vysotskii 및 Kornilova는 방사선 환경에서 단일 미생물에 비해 공생 관계를 이루는 복 합미생물의 생존 기간이 3 배 이상 늘어난다는 것을 보고하였 다. ${ }^{12)}$ 또한 Shuryak 등도 여러 미생물들이 군집을 이루고 있으 면 전체적인 내 방사선 특성이 증가한다는 연구 결과를 발표 하였으며 이것은 미생물들 간의 협력에 의해 활성종에서 빚어 지는 산화적 스트레스를 이겨내는 능력이 향상되는 것과 연관 이 있음을 밝혔다. ${ }^{13)}$ 본고에서는 상생 관계를 이루는 복합미 생물을 제조하여 굴 껍데기를 포함한 폐패각류를 소멸 처리한 실험 결과를 보고하였다.

\section{2. 실험}

\section{1. 복합미생물 제조 및 동정}

실험에 사용할 복합미생물을 확보하기 위하여 석회암 지역 일대 및 폐패각을 오랫동안 쌓아 둔 곳 등의 바닥에서 토양을 채취하였다. 여기에 고온에서 견딜 수 있는 미생물을 확보하 기 위하여 화산암 지역에서 채취한 토양을 추가하였다. 일반 적으로 토양미생물을 분리, 확보하는 방법으로서 농화배양법 을 활용하며 이것은 미생물의 분리, 동정을 위한 필수적인 과 정이기도 하다. 그러나 본 실험에서는 상생관계를 이루는 복 합미생물을 직접 제조하기 위하여 여러 곳에서 채취한 토양을 그대로 혼합한 다음에 혐기성 조건과 호기성 조건을 주기적으 로 교체하여 가면서 한 달여 이상 장기간 액상 배양하여 안정 적인 생태계가 이루어지도록 하였다.

복합미생물 군집분석을 위하여 분해 실험 전, 실험 개시 후 29시간 및 77시간 시점에서 각각 시료를 채취하여 분석하였 다. 시료로부터 전체 미생물 DNA를 MP Bio사의 Fast kit for Soil DNA (MP BIO, Santa Ana, CA, USA)를 이용하여 분리 하고 $16 \mathrm{~S}$ rRNA 유전자를 barcoded primer를 이용하여 증폭한 후 분석하였다. 차세대 염기서열 분석 방법(Illumina Miseq 


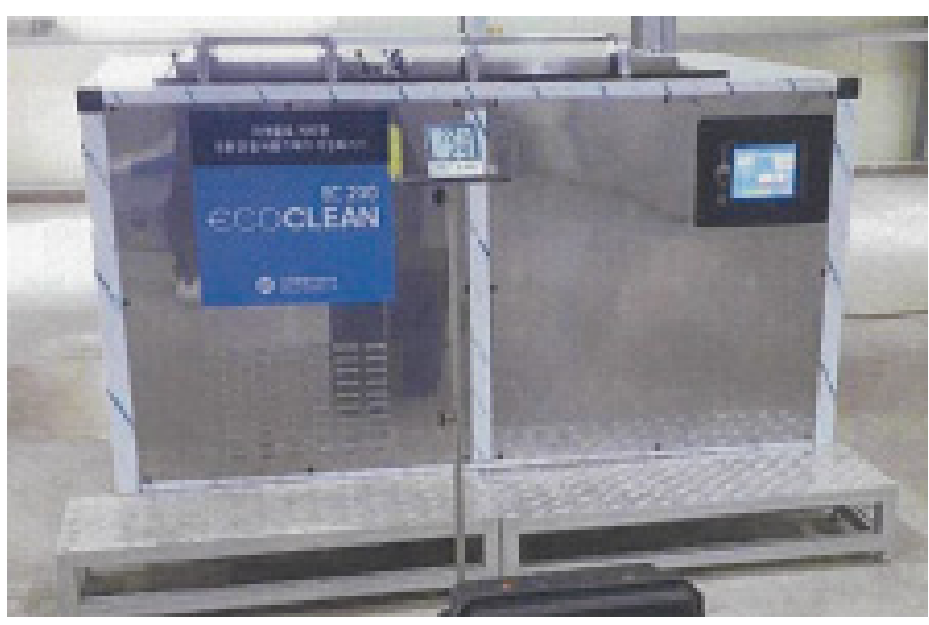

(a) Waste food decomposer

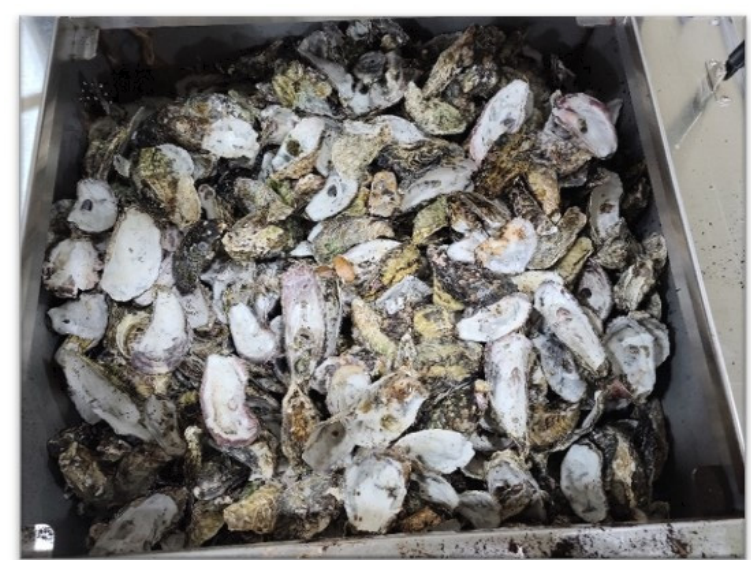

(c) Shells loaded in the waste food decomposer

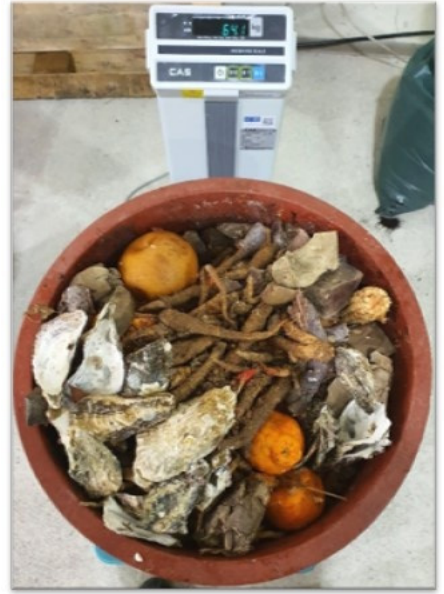

(b) Mixture of waste shells and waste food

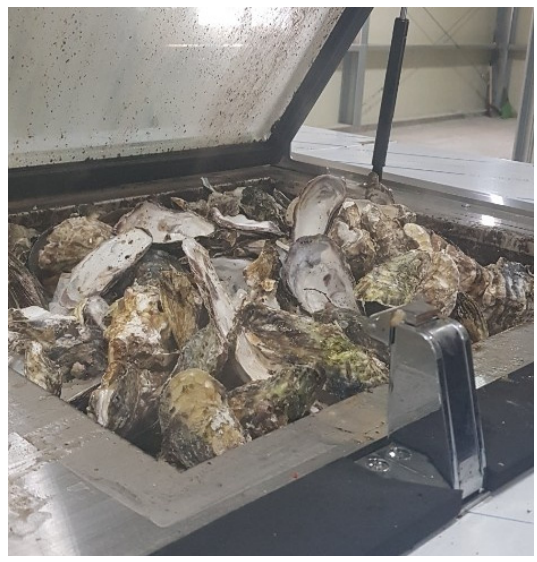

(d) Oyster shells in the waste food decomposer

Fig. 1. Waste food decomposer and mixture of waste food and shells charged into it.

platforms)으로 염기서열을 분석하여 sequence read들을 획 득하였다. 이 방법으로 획득한 $16 \mathrm{~S}$ rRNA 유전자 서열들을 QIIME2 pipeline을 이용하여 Greengenes 16S rRNA gene 데 이터베이스와 비교하여 각 염기서열을 동정하였다.

\section{2. 복합미생물을 이용한 음식물류 폐기물 및 폐패각 혼합 물 감량 소멸 처리}

미생물을 이용한 음식물류 폐기물 처리기로서는 국내 최초 로 환경부 기준에 적합한 품질인증( $\mathrm{Q}$ 마크)을 받은 미라클에 코바이오(주) 사의 음식물류 폐기물 감량부숙기(Eco Clean EC-200)를 사용하였다. 한국건설생활환경시험연구원에서 발 급한 시험성적서에 의하면 5일 동안 매일 약 $200 \mathrm{~kg}$ 의 음식물 쓰레기를 투입하고 9 일 후 $2 \mathrm{~kg}$ 이 잔류하여 감량율 $99 \%$ 라는 놀라운 성능을 보이는 것으로 확인되었다. 내부온도가 78.5 ${ }^{\circ} \mathrm{C}$ 로서 내열성이 우수한 복합미생물을 활용한 제품이며 고 온에서 처리하기 때문에 단기간에 소멸처리가 가능하였던 것 으로 추정된다.

실험에 사용한 굴 껍데기 및 폐패각은 식당에서 발생하는
폐기물을 사용하였다. 음식물 쓰레기와 각종 패각류(굴, 전복, 모시조개, 소라, 바지락 등)를 부피 비로 대략 1:1로 혼합하여 미생물 처리기에 투입하였다. 폐패각들을 별도의 파쇄작업을 거치지 않고 생긴 형상 그대로 투입하였다. 투입한 양은 중량 으로 $40 \mathrm{~kg}$ 이었으며 교반을 시작하면서 액상의 복합미생물 2리터를 흘려 넣었다.

미생물 처리기를 $80{ }^{\circ} \mathrm{C}$ 의 온도에서 가동을 시작하고 48 시 간 및 72 시간 후 폐기물 분석용 시료를 채취하였다. 미생물 분석용 시료는 29 시간 및 77 시간 처리 후에 채취하였다. Fig. 1은 음식물류 폐기물 감량 부숙기 및 실험에 사용한 폐패각 들, 그리고 음식물류 폐기물과 패각류를 부숙기에 장입한 모 습이다. Fig. 2는 장입된 음식물류 폐기물과 폐패각의 혼합물 이 시간이 지남에 따라 형상이 변하는 것을 순차적으로 보여 준다.

폐기물 분석용 시료를 채취한 후, 시료를 알코올 및 증류수 로 초음파 세척을 하여 유기물을 씻어내고 남은 무기물을 대 상으로 시료의 형상과 결정구조 해석을 위하여 주사전자현미 경(SEM, JEOL, JSM-7100F) 관찰 및 XRD(Bruker AXS, D8 


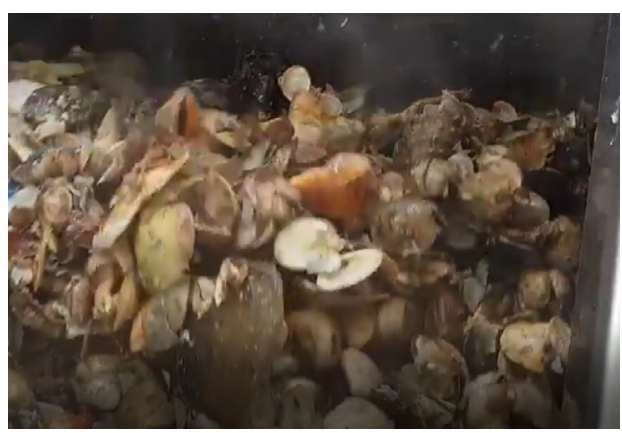

(a) 0 hour

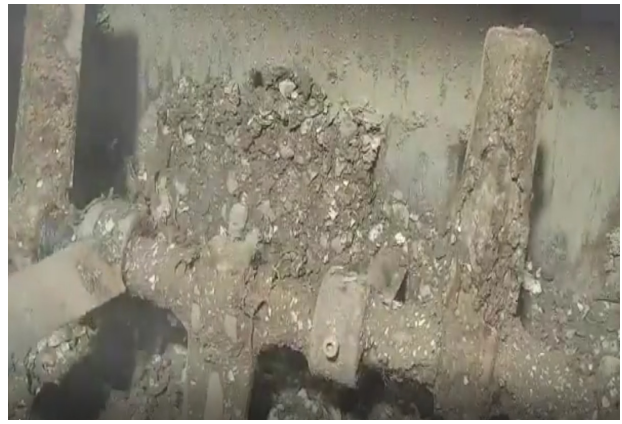

(c) 11 hours

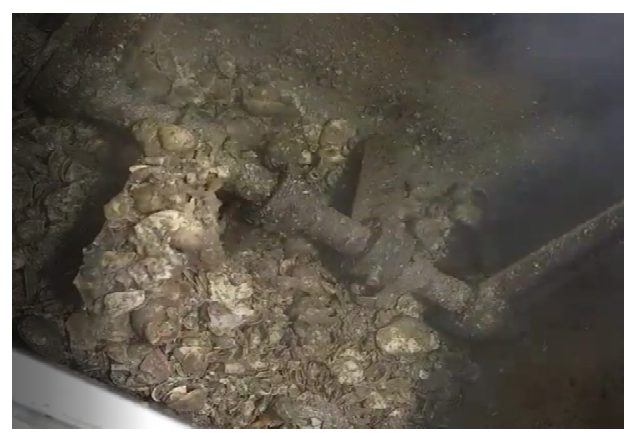

(b) 3 hours

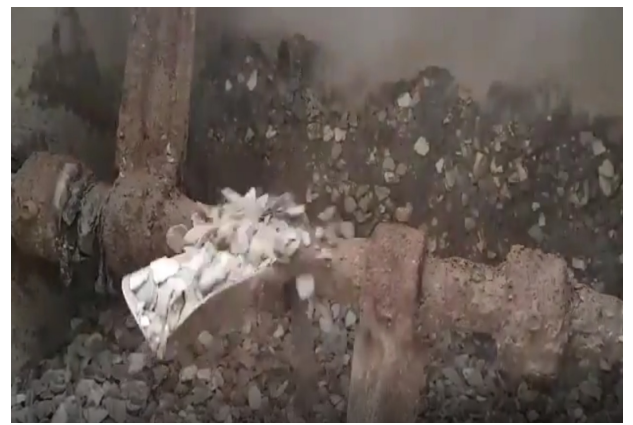

(d) 29 hours

Fig. 2. Morphology change of the waste food and oyster shell mixture over the time of treatment with microorganisms.

Advance) 분석을 실시하였다. 또한 분해 생성물의 특성을 확 인하고자 진한 염산 $20 \mathrm{ml}$ 에 시료 $1 \mathrm{~g}$ 을 투입하여 염산과 반 응시킨 후 중량 변화를 측정하였다. 열 분해 특성을 관찰하기 위하여 시차열분석(DTA) 및 중량열분석(TG, Perkin Elmer, STA 8000)을 하였다. 이와 별도로 $550{ }^{\circ} \mathrm{C}, 700{ }^{\circ} \mathrm{C}, 900{ }^{\circ} \mathrm{C}$ 에서 1 시간 동안 열처리를 하면서 형상 변화를 관찰함과 동시에 중량 변화를 측정하였다.

\section{3. 실험 결과}

\section{1. 미생물총 변화}

복합미생물을 제조하여 장기간 배양한 후 미생물 농도를 분 석한 결과 $5.6 \times 10^{2} / \mathrm{ml}$ 이었다. 동정 결과 170 속, 310 종의 미 생물이 존재하는 것으로 확인되었으며 우점 군집은 Table1과 같았다. 주요 구성 미생물은 Propionibacterium 으로서 $76.5 \%$ 를 차지하고 혐기성 미생물이다. 그 다음으로 유산균으로 알 려진 Lactobacillus 가 7.1\%, 그 뒤를 이어 Megasphaera (6.9 $\%)$ 가 비슷한 수준이었다. 그 다음으로 Komagataeibacter (4.4 $\%)$ 와 Acetobacter (3.9\%, 초산균)가 비슷한 규모로 존재하는 것으로 나타났다. 그 다음에는 절대혐기성인 Parabacteroides가 $1.1 \%$ 를 차지하였다. 특기할 사항은 Lactobacillus 는 혐기성 미생물이나 공기 중에서도 생존이 가능한 준 호기성 미생물이 고, Komagataeibacter 및 Acetobacter는 호기성 미생물이다. 전체적으로 혐기성 미생물과 호기성 미생물이 공존하는 것 을 알 수 있다. 이 복합미생물은 서로가 공생하는 하나의 생
Table 1. Composition of the prepared multi-complex microorganisms.

\begin{tabular}{cc} 
Genus & $\%$ \\
Propionibacterium & 76.5 \\
\hline Lactobacillus & 7.1 \\
\hline Megasphaera & 6.9 \\
\hline Komagataeibacter & 4.4 \\
\hline Acetobacter & 3.9 \\
\hline Parabacteroides & 1.1 \\
\hline
\end{tabular}

태계를 이루고 있어 환경에 대한 저항력이 높아져 $80{ }^{\circ} \mathrm{C}$ 의 처리 온도에서도 사멸되지 않고 대사작용이 가능했던 것으 로 보인다.

실험을 진행하면서 일어나는 미생물총의 조성 변화를 파악 하고자 29시간 및 77시간 후 채취한 시료들을 문(Phylum)을 기준으로 하여 분석한 결과 Table 2와 같은 결과가 얻어졌다. 실험을 시작하기 전의 미생물총의 구성을 보면 Firmicutes가 $42 \%$ 를 차지하고 나머지는 Bacteroidota와 Actinobacteriota가 반분하는 비율로 이 3 종이 거의 대부분을 차지하고 있다. 그 러나 실험을 시작하고 29시간 후에는 Proteobacteria가 반을 차지하는 구조로 변화하였고 Firmicutes 와 Bacteroidota는 그 비중이 대폭 감소하였다. 77시간 후에는 그 비중이 Firmicutes $A$ 로 이동하였다. 이 결과는 미생물들이 고온 환경에서 생존하 면서 계속 대사작용을 하고 있었음을 시사한다. 


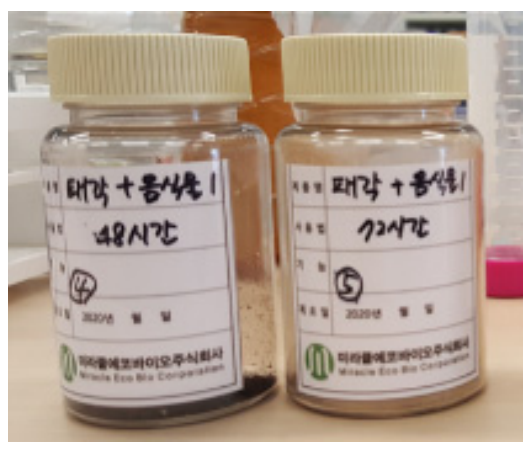

(a) Specimen in a glass bottle with a treatment time on the label

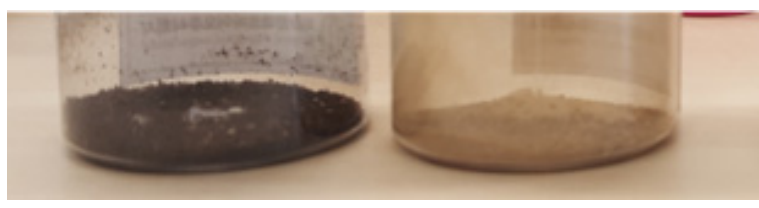

(b) Close-up view of specimen. Left, 48 hours of treatment and right, 72 hours of treatment

Fig. 3. Specimens were obtained after the treatment of 48 hours and 72 hours, respectively.

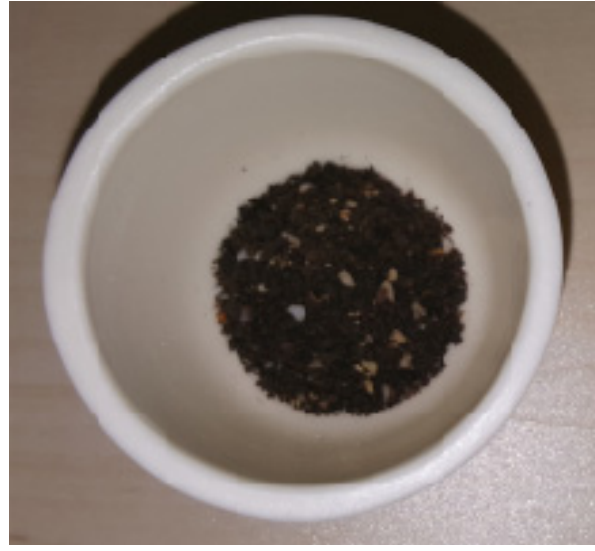

(a) 48 hours of treatment

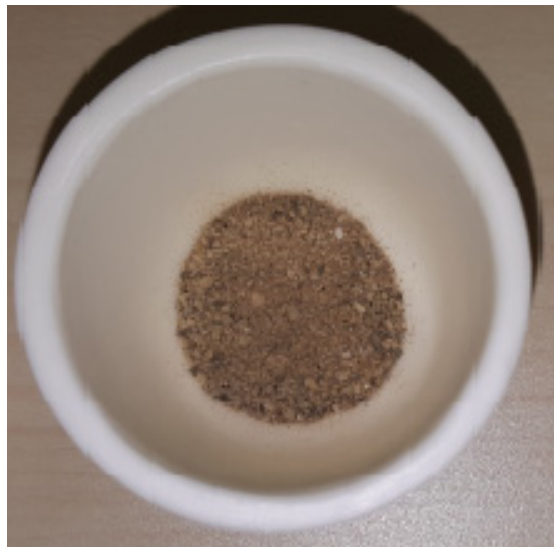

(b) 72 hours of treatment

Fig. 4. The shape of the samples collected after treatment of 48 hours and 72 hours. It was photographed after heating at $120^{\circ} \mathrm{C}$ for 30 minutes in order to dry.

Table 2. Changes in the composition of the multi-complex microorganisms over time.

\begin{tabular}{cccc} 
Phylum & 0 hour & 29 hours & 77 hours \\
Firmicutes & 42.48 & 11.01 & 8.26 \\
\hline Bacteroidota & 27.25 & 3.32 & 3.45 \\
\hline Actinobacteriota & 26.93 & 14.39 & 13.15 \\
\hline Proteobacteria & 6.04 & 54.58 & 16.09 \\
\hline Firmicutes $C$ & 2.99 & 0 & 0 \\
\hline Firmicutes $A$ & 1.09 & 6.61 & 57.49 \\
\hline Patescibacteria & 0.01 & 5.84 & 0.67 \\
\hline Others & 0.74 & - & - \\
\hline Uncharacterized & 0.16 & 4.3 & 0.9 \\
\hline
\end{tabular}

\section{2. 형상 및 중량 변화}

폐패각류를 음식물류 폐기물과 함께 처리기에 투입한 후 시 간에 따른 중량 변화를 측정한 결과 초기 투입 시 약 $40 \mathrm{~kg}$ 이상이었으나 48 시간이 지나면서 현저하게 줄어들었고 72 시 간 이후에는 $4 \mathrm{~kg}$ 이하로 줄어들었다. 초기에는 음식물 쓰레 기와 폐패각들이 형상을 유지하고 있었으나 24시간이 지나면
서 패각류 고유 형상이 거의 사라졌다. 또한 굴 껍데기를 포함 한 폐패각들의 울퉁불퉁한 형상 때문에 부피가 컸던 것이 작 은 미립자 형태로 분해되면서 부피가 현저하게 줄어들었다. 72 시간 후에는 반 건조 상태의 구형 입자들로 바뀌면서 커다 란 패각 껍질들이 모두 소멸되었다. 시료의 색깔에서도 변화 가 관찰되었다. Fig.3과 4에서 보듯이 48시간 후 채취한 시료 의 색깔은 검은색이었으나 72 시간 처리 후에는 갈색으로 변 하였다. 이러한 차이는 유기성폐기물 성분의 소멸처리 정도에 따라 색깔이 달라진 데서 기인하는 것으로 판단된다.

폐패각의 종류에 따라서도 분해 속도에 차이가 있는 것으로 관찰되었다. 전복 및 소라는 상당히 껍질이 단단하여 비교적 시간이 걸렸으나 굴 껍데기는 쉽게 분해되었다. Fig.4는 최종 산물을 $120{ }^{\circ} \mathrm{C}$ 에서 30 분 동안 가열하여 건조한 후 촬영한 것 으로서 패각이 작은 조각들로 분해된 것을 볼 수 있다.

\section{3. 주사전자현미경 관찰 및 XRD 분석}

채취한 시료를 각 시료별로 $\mathrm{SEM}$ 관찰 및 $\mathrm{EDX}$ 분석, $\mathrm{XRD}$ 분석을 하였다. SEM관찰 결과 Fig.5에서 보듯이 시료의 형 

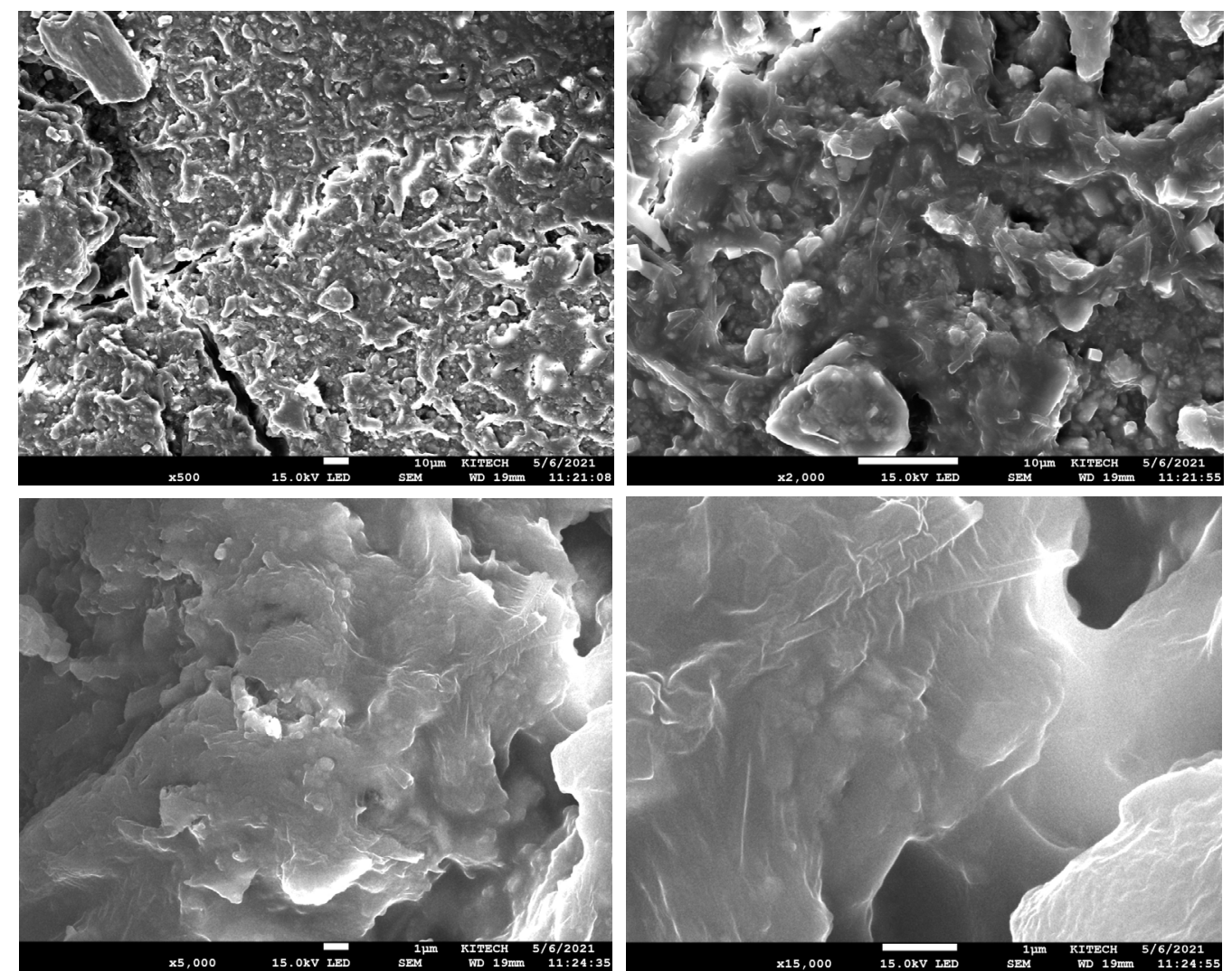

(a) After 48 hours of treatment. From the top left, 500X, 2 k, 5 k, and 15 k, respectively. Thin organic film covering the particles is observed.
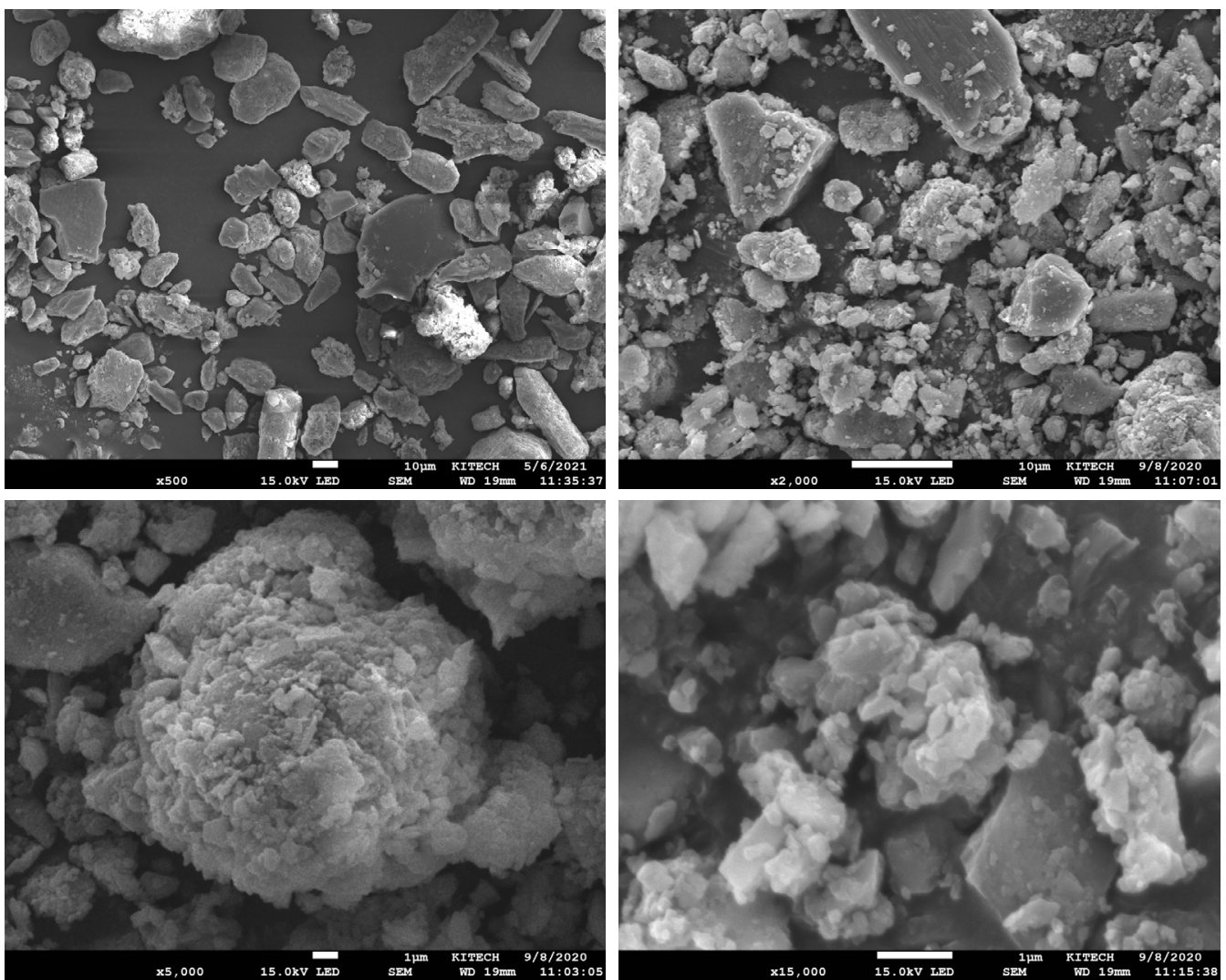

(b) After 72 hours of treatment. From the top left, 500X, 2 k, 5 k, and 15 k, respectively. Thin film has been disappeared.

Fig. 5. Scanning electron microscopy of samples treated for 48 hours and 72 hours. 


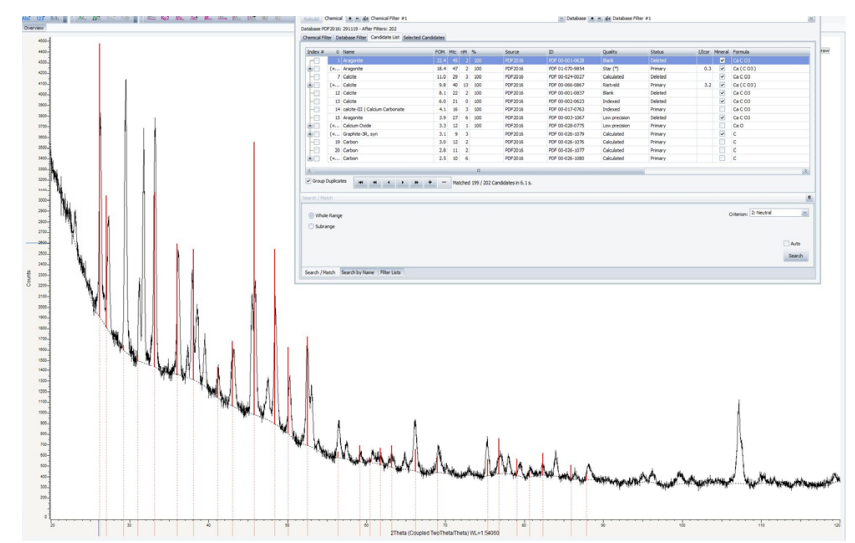

(a) After 48 hours of treatment

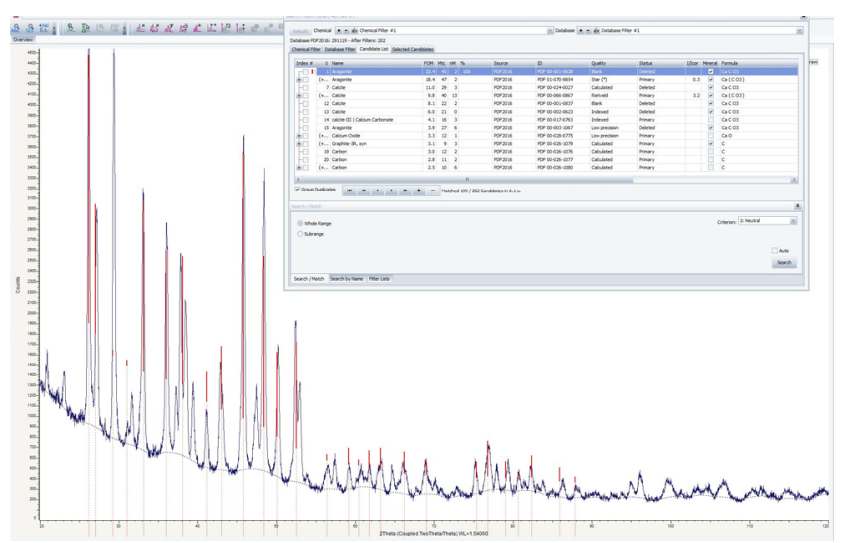

(b) After 72 hours of treatment

Fig. 6. Results of X-Ray diffraction analysis. Red peak is for aragonite and blue peak is for calcite.

상이 불규칙하였으며 유기성 잔류물도 관찰되었다. 48시간 처리 한 시료는 조각의 크기가 큰 것은 $1 \mathrm{~mm}$ 내외이었고 작은 것은 $10 \mu \mathrm{m}$ 이하였다. 72시간 후에는 큰 덩어리들이 약 $20 \mu \mathrm{m}$ 내외, 작은 것들은 $1 \mu \mathrm{m}$ 이하가 될 정도로 현저하 게 크기가 작아졌다. 또한 48시간 처리한 시료에서는 같이 장입된 유기성 폐기물에 의한 막이 존재하고 그 안에 직경 $1 \mu \mathrm{m}$ 크기의 구상 미생물들이 있는 것으로 관찰되었다. 72시 간 처리한 시료에서는 이러한 얇은 막이 사라진 것을 알 수 있는데 이것은 미생물에 의한 유기성 폐기물의 분해 소멸이 충분히 일어났다는 것을 시사한다. 이로부터 유기성 폐기물 을 충분히 소멸시키려면 최소한 48 시간 이상 처리해야 하는 것으로 추정된다.

입자들의 조성을 $\mathrm{EDX}$ 로 분석한 결과 입자나 위치에 따라 결과가 달라지기 때문에 일률적으로 표현하기는 어려우나 검 출된 주요 피크는 탄소, 산소, 칼슘이었다. 이 중에서 탄소 함량은 $20 \%$ 대에서 $10 \%$ 대로 처리 시간에 따라 감소하였으 며 이것은 유기성 폐기물이 분해되면서 탄소 함량이 줄어들 었음을 의미하는 것으로 해석된다. 산소는 평균적으로 $40 \%$ $50 \%$ 대를 유지하였고 칼슘은 $30 \%$ 대에서 $40 \%$ 대로 증가 하였다. 이것은 유기성 폐기물에서 오는 탄소가 분해되어 소 멸되면서 상대적으로 칼슘의 함량이 높아진 때문인 것으로 추정된다.

XRD 분석 결과 Fig.6에서와 같이 주로 방해석(Calcite)과 아라고나이트(Aragonite)가 관찰되었으며 다만 72시간 처리 한 시료에서 방해석의 피크가 상대적으로 감소한 것을 알 수 있었다. 그러나 탄산칼슘이 분해되어 생성되는 생석회 $(\mathrm{CaO})$ 는 양쪽 모두 나타나지 않았다. 생석회가 수화반응을 일으켜 생성되는 수산화칼슘도 관찰되지 않았다.

\section{4. 시차 열분석 및 중량 열분석}

채취한 시료의 열 특성을 관찰하기 위하여 시차열분석 (DTA) 및 중량 열분석(TG)을 실시하였다. Fig.7은 측정 결
과로서 (a)는 48 시간 처리 후 시료이고 (b)는 72시간 처리 후 시료이다. 아르곤 가스를 $20 \mathrm{ml} / \mathrm{min}$ 유량으로 흘려주었고 승 온속도는 $10{ }^{\circ} \mathrm{C} / \mathrm{min}$ 으로 설정하였다. 48 시간 처리한 시료에 서는 총 감량 비율이 초기 중량 대비 $62.1 \%$ 이었다. $200{ }^{\circ} \mathrm{C} \sim 400$ ${ }^{\circ} \mathrm{C}$ 온도 범위에서는 초기 중량 대비 $33.4 \%$ 의 감량이 일어났 다. 이것은 시료에 남아 있는 유기물 성분이 분해되면서 일어 난 현상으로 추정된다. 탄수화물, 단백질, 지질 등의 분해 온도가 각기 $164{ }^{\circ} \mathrm{C} \sim 497{ }^{\circ} \mathrm{C}, 209{ }^{\circ} \mathrm{C} \sim 309{ }^{\circ} \mathrm{C}, 200{ }^{\circ} \mathrm{C} \sim 635^{\circ} \mathrm{C}$ 라는 것을 고려하면 충분히 개연성이 있다고 볼 수 있다. ${ }^{14)}$ 2 단계 감량은 $650{ }^{\circ} \mathrm{C} \sim 750{ }^{\circ} \mathrm{C}$ 사이에서 일어났는데 이것은 $\mathrm{CaCO}_{3}$ 가 $\mathrm{CaO}$ 와 $\mathrm{CO}_{2}$ 로 분해되면서 일어나는 현상으로 판단 된다. ${ }^{15)}$ 이 온도 범위에서의 중량 감소량은 초기 중량 대비 $11.8 \%$ 로서 유기물의 분해에 의한 1 단계 감량보다 작게 나타 났다.

72시간 처리한 시료에서는 총 감량 비율이 초기 중량 대비 $47.2 \%$ 이었다. 이 결과는 유기물 성분이 48 시간 처리한 시료 보다 더 많이 줄어들었기 때문으로 추정된다. 실제로 $200{ }^{\circ} \mathrm{C}$ $\sim 400{ }^{\circ} \mathrm{C}$ 온도 범위에서 초기 중량 대비 $11.3 \%$ 의 감량이 일어 났다. 2 단계 감량은 마찬가지로 $650{ }^{\circ} \mathrm{C} 750{ }^{\circ} \mathrm{C}$ 사이에서 일어 났는데 감량 개시 및 종료 온도가 보다 분명하게 나타났다. 이 분해 온도 범위는 $700{ }^{\circ} \mathrm{C}$ 에서 분해가 시작되어 $850{ }^{\circ} \mathrm{C}$ 에서 분해가 완료되었다는 보고 ${ }^{16)}$ 및 $570{ }^{\circ} \mathrm{C}$ 에서 분해가 시작되어 $760{ }^{\circ} \mathrm{C}$ 에서 분해가 완료되었다는 연구 결과와 일치하는 범위 이다. ${ }^{17)}$ 중량 감소량은 초기 중량 대비 $28.9 \%$ 로서 유기물의 분해에 의한 1 단계 감량보다 크게 나타났다. Table 3은 열분 석 결과를 정리한 것이다.

열의 흐름을 나타내는 결과는 48 시간 처리한 시료와 72 시간 처리한 시료의 경향이 반대로 나타났다. 48 시간 처리한 시료 에서는 고온으로 접근할수록 흡열 현상이 나타났으나 72 시간 처리한 시료에서는 고온으로 갈수록 발열 현상이 관찰되었다. 이러한 결과가 얻어진 원인은 불분명한 상태이다. 


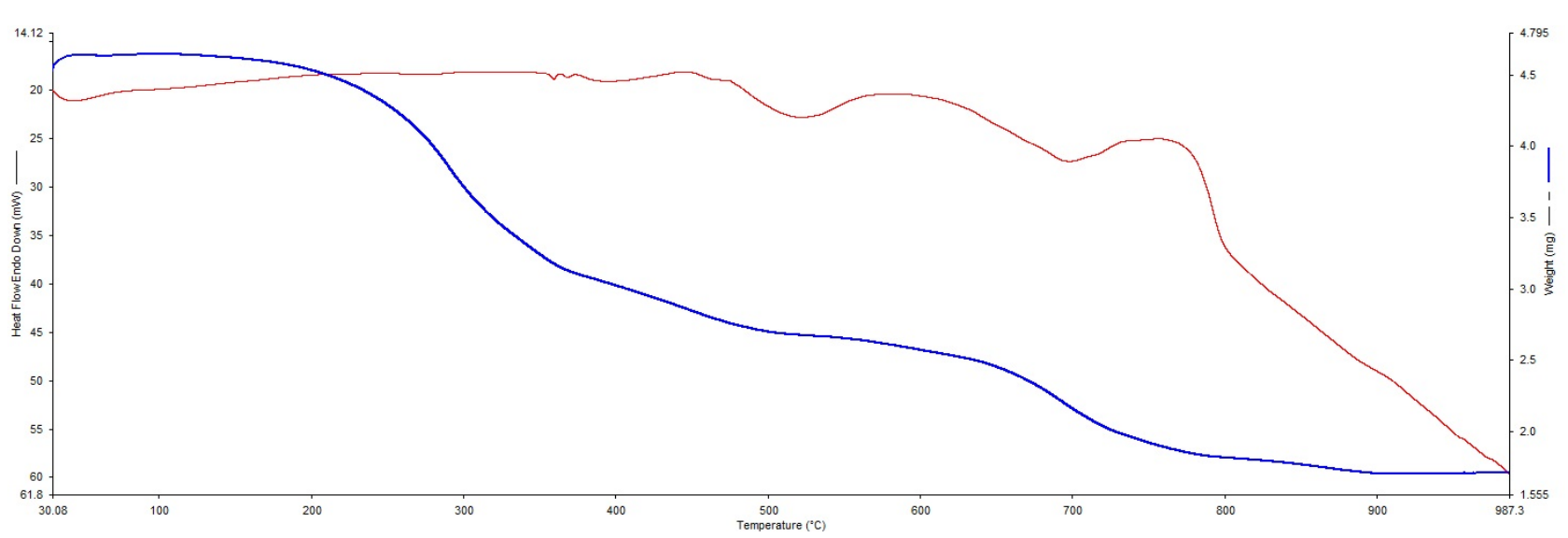

(a) After 48 hours of treatment. Red curve is for heat flow (endo down) and blue curve is for weight change.

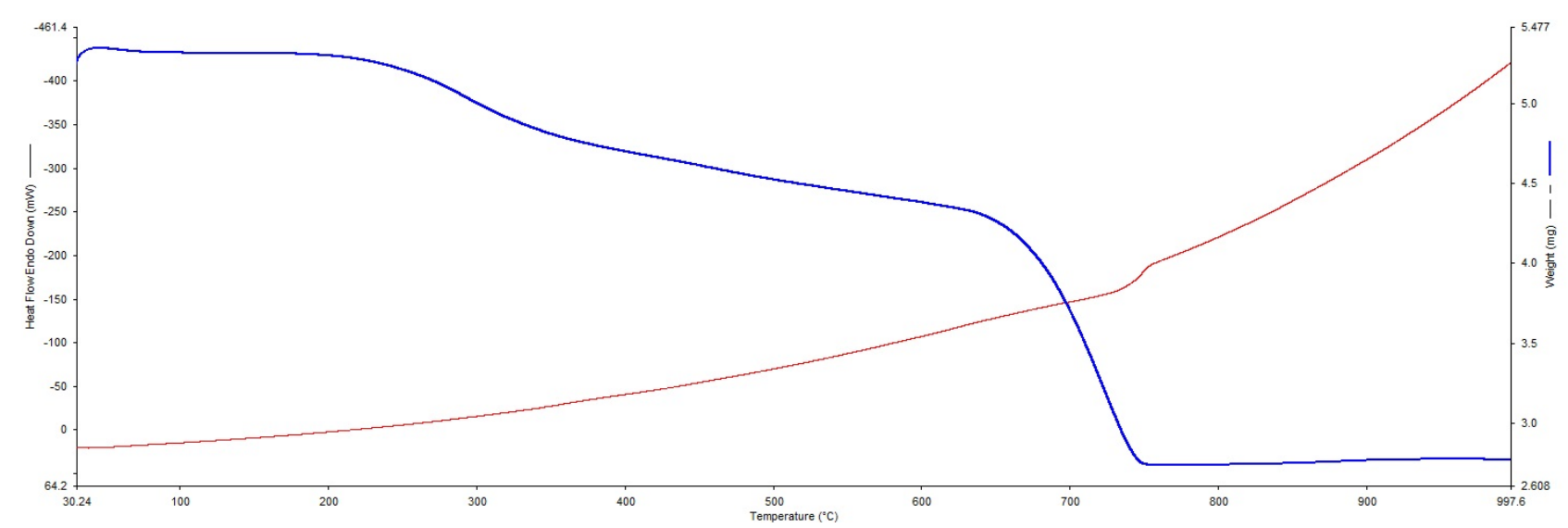

(b) After 72 hours of treatment. Red curve is for heat flow (Endo down) and blue curve is for weight change.

Fig. 7. Results of thermogravimetry and differential thermal analysis (TG/DTA).

Table 3. Summary of the TG/DTA analysis.

\begin{tabular}{cccc} 
Temperature range & $200{ }^{\circ} \mathrm{C} \sim 400^{\circ} \mathrm{C}$ & $650^{\circ} \mathrm{C} \sim 750^{\circ} \mathrm{C}$ & \multicolumn{2}{c}{ Total weight loss } \\
Weight loss of samples treated for 48 hours & $33.4 \%$ & $11.8 \%$ & $62.1 \%$ \\
\hline Weight loss of samples treated for 72 hours & $11.3 \%$ & $28.9 \%$ & $47.2 \%$ \\
\hline
\end{tabular}

Table 4. Weight loss after heat treatment of $1 \mathrm{~g}$ of samples for 1 hour. (unit; g)

\begin{tabular}{cccccc} 
Heating Temperature & $120^{\circ} \mathrm{C}$ & $550{ }^{\circ} \mathrm{C}$ & $700^{\circ} \mathrm{C}$ & $900^{\circ} \mathrm{C}$ & \multicolumn{2}{c}{ Total weight loss } \\
Samples treated for 48 hours & -0.05 & -0.55 & -0.14 & -0.05 & -0.79 \\
\hline Samples treated for 72 hours & -0.03 & -0.31 & -0.26 & -0.02 & -0.62 \\
\hline
\end{tabular}

\section{5. 열처리 및 중량 감량 측정}

탄산칼슘과 유기물의 분해 온도가 다르다는 점에 착안하여 열처리 온도를 달리하면서 중량 감소를 측정하였다. 일차적으 로 수분을 제거하기 위하여 $120{ }^{\circ} \mathrm{C}$ 온도에서 30 분 열처리를 한 다음에 중량을 측정하고 순차적으로 각 온도별로 가열 처 리, 냉각, 중량 측정의 순서를 거쳤다. 시료 $1 \mathrm{~g}$ 을 도가니에 넣고 뚜껑을 닫은 후 각 온도에서 1 시간 동안 동시에 같이 열처리하였다. Table 4는 열처리 온도와 온도별 중량 감소량 을 보여준다. Table4의 결과를 그래프로 나타낸 Fig. 8을 보면
$120{ }^{\circ} \mathrm{C}$ 에서 $550{ }^{\circ} \mathrm{C}$ 사이의 온도에서 48 시간 처리한 시료의 감량이 72 시간 처리한 시료의 감량보다 휠씬 크다는 것을 알 수 있다. 또한 $550{ }^{\circ} \mathrm{C}$ 에서 $700{ }^{\circ} \mathrm{C}$ 온도 범위에서는 72 시간 처 리한 시료의 중량 감량이 더 큰 것으로 나타났다. 이것은 앞서 Fig.7의 열분석 결과와 일치하는 내용이다. 또한 열처리 후에 흰색으로 모습이 드러난 조개 껍질들의 형상을 보면 Fig.9에 서 보듯이 처리 시간이 길수록 더욱 잘게 쪼개진 것을 확인할 수 있다.

고온에서 탄산칼슘이 산화칼슘과 이산화탄소로 분해될 경 


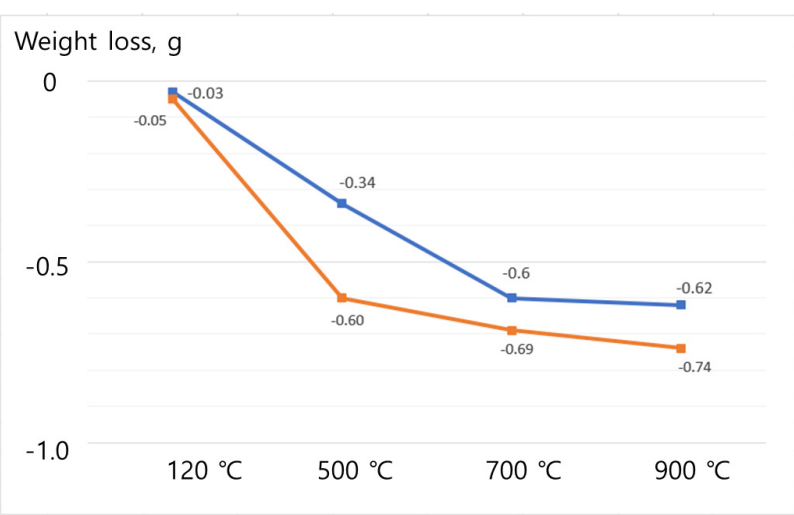

Fig. 8. Accumulated weight reduction after 1 hour of heat treatment at each temperature. (Blue line and brown line are the curves of the samples treated for 72 hours and 48 hours, respectively.) Samples were dried at $120^{\circ} \mathrm{C}$ for 30 minutes before heat treatment.
우, 예상되는 중량 감소량은 $44 \%$ 가 된다. 48 시간 처리한 시료 및 72 시간 처리한 시료에서 총 중량 감소량이 각기 $79 \%$ 및 $62 \%$ 가 되었다는 것은 시료에 유기질 성분이 상당히 포함되 어 있음을 시사한다.

\section{6. 염산 반응 실험}

탄산칼슘 $\left(\mathrm{CaCO}_{3}\right)$ 은 염산과 반응하여 생석회와 이산화탄 소로 분해된다. 이를 확인하기 위하여 진한 염산 $20 \mathrm{ml}$ 에 시료 각 $1 \mathrm{~g}$ 을 투입하여 화학반응이 끝난 후 중량 변화를 측정하였다. 중량 변화는 아래의 Table 5와 같이 72시간 처 리한 시료의 감량이 훨씬 많았다. 또한 염산과 반응하는 과 정을 살펴본 결과 72 시간 처리한 시료가 Fig. 10 에서처럼 48 시간 처리한 시료보다 더 격렬하게 반응하여 끓어오르는 현 상이 관찰되었다.

Samples treated for 48 hours
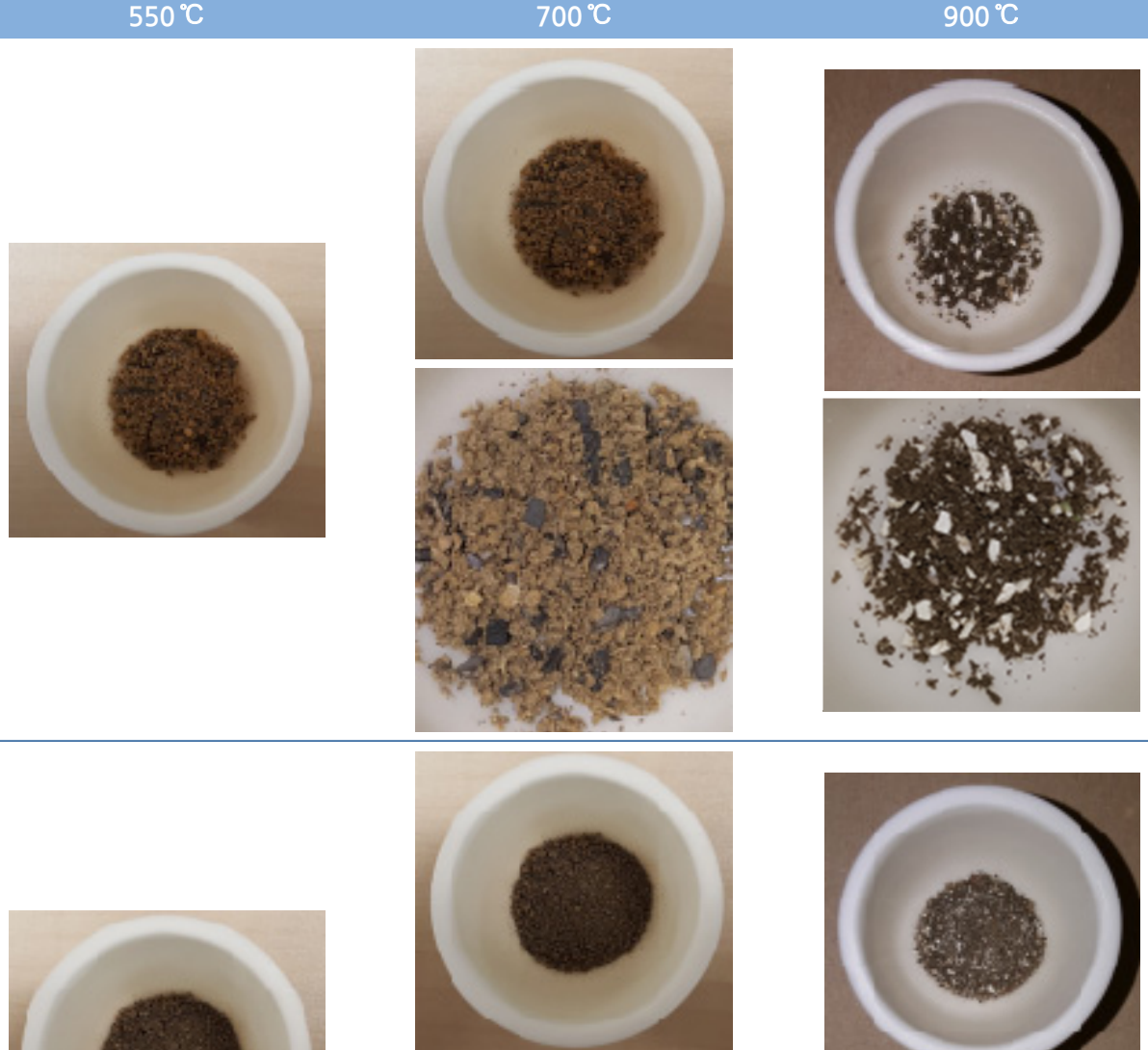

Samples treated for 72 hours
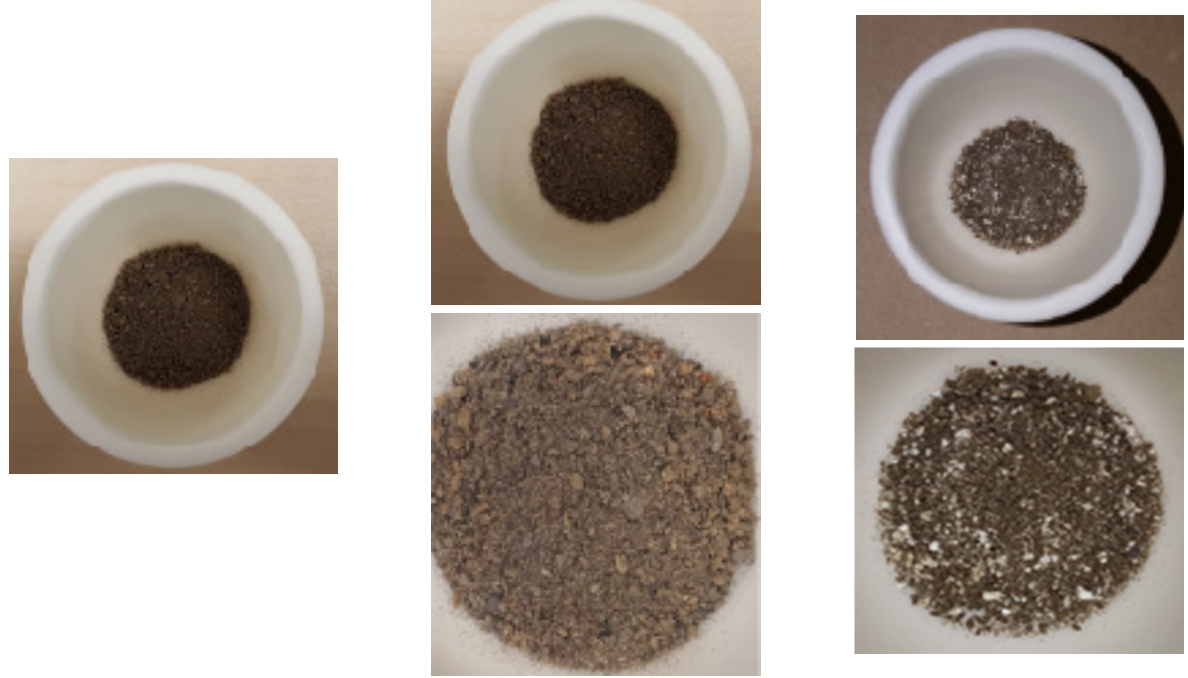

Fig. 9. Photography of samples after heat treatment at each temperature for 1 hour. 
Table 5. Weight loss of treated shell samples after mixed with concentrated hydrochloric acid. $1 \mathrm{~g}$ of sample was mixed with $20 \mathrm{ml}$ of concentrated $\mathrm{HCl}$. (unit; g)

\begin{tabular}{cccc} 
Treatment time of samples & 48 hours & 72 hours \\
Weight loss right after the mixing with HCl solution & -0.08 & -0.23 \\
\hline 11 minutes later after mixing & -0.08 & -0.23 \\
\hline 40 hours later after mixing & -0.12 & -0.27 \\
\hline
\end{tabular}

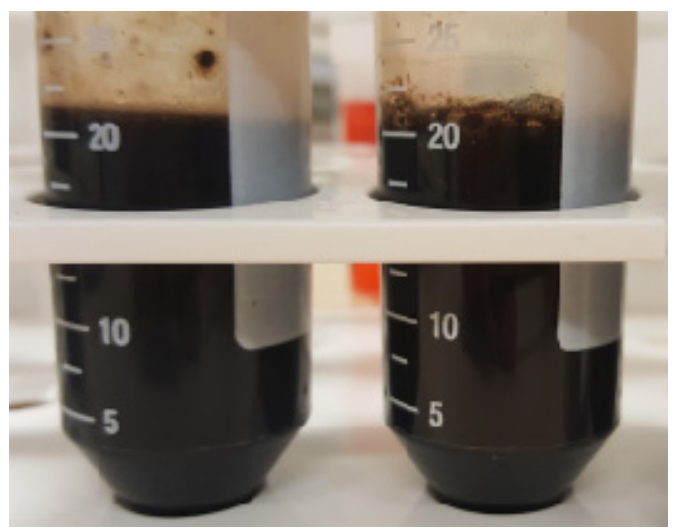

Fig. 10. Photographs were taken after mixing the samples with concentrated hydrochloric acid. Left is a sample treated for 48 hours and right is a sample treated for 72 hours. An aggressive reaction was observed for the sample treated for 72 hours.

\section{4. 고 찰}

본 실험에서 사용한 복합미생물의 조성을 보면 일반적인 토 양환경미생물들로서 생존 온도 내지는 활성 온도가 대부분 상온 영역에 머무르는 것들이다. 그럼에도 불구하고 실험 온 도인 $80{ }^{\circ} \mathrm{C}$ 에서 죽지 않고 생존하여 폐패각과 음식물류 폐기 물의 혼합물이 분해되는 결과를 얻을 수 있었다. 실험 후 채취 한 시료를 배양, 분석한 결과 군집의 조성에서 변화가 있었으 나 미생물들이 죽지 않고 살아 있는 것이 확인되었다. 미생물 들이 고온에서 죽지 않고 생존하였다는 것은 분해 기전이 미 생물들의 작용에 의한 것임을 뒷받침한다. 또한 이로부터 여 러 미생물들이 공존하는 생태계를 이룰 경우, 내환경 특성이 증진된다는 것을 확인할 수 있다. 이러한 사례는 내방사선 미 생물을 이용한 연구 분야에서 주로 보고되고 있기 때문에 앞 으로 미생물의 응용 방법에 있어서 생태계를 이루는 복합미생 물의 활용법에 대해 보다 많은 연구가 이루어져야 할 것으로 생각된다.

조개 껍질은 탄산칼슘 $\left(\mathrm{CaCO}_{3}\right)$ 이 주성분이며 탄산칼슘은 결 정구조에 따라 방해석(Calcite)과 아라고나이트(Aragonite)로 나누어진다. 방해석은 육각형 기둥 모양의 육방정계이고, 아 라고나이트는 직각기둥 모양의 사방정계이다. 굴 껍데기는 주 로 방해석으로 구성되어 있고 대합, 꼬막, 바지락은 대부분 아라고나이트로 구성되어 있다. 조개 껍질의 특이한 점은 탄 산칼슘 층 사이에 단백질의 일종인 콘키올린(conchiolin)이 있
어 서로 교차하면서 층상구조를 이룬다는 사실이다. ${ }^{18)}$ 따라서 이 단백질 층이 미생물의 먹이가 되면 층상 구조가 분리되면 서 조개 껍질이 쉽게 분해될 것으로 예상할 수 있다. 본 실험 에서 불과 24시간 만에 폐패각들의 형상이 없어질 정도로 분 해될 수 있었던 것은 미생물에 의해 층상 구조가 파괴된 때문 인 것으로 추정된다.

그러나 층상구조가 파괴되었다 하여도 조개 껍질이 계속 탄 산칼슘으로 존재한다면 미생물 처리에 의한 중량 감량을 설명 하기가 어렵다. 탄산칼슘은 잘 알려져 있듯이 $900{ }^{\circ} \mathrm{C}$ 근방에 서 아래와 같은 반응식 (1)을 거쳐 생석회 $(\mathrm{CaO})$ 가 된다. 복합 미생물 처리기의 내부 온도가 $80{ }^{\circ} \mathrm{C}$ 이므로 탄산칼슘의 열 분 해는 불가능하다. 그러나 폐패각류를 포함한 총 중량이 초기 장입 중량 대비 $10 \%$ 이하로 줄어든 것은 수분과 유기성 음식 물류 폐기물의 함량을 고려한다고 하여도 달리 설명할 길이 없으므로 복합미생물에 의해 탄산칼슘이 분해되어 생석회가 생성되었을 가능성을 검토하지 않을 수 없다.

$$
\mathrm{CaCO}_{3}(\mathrm{~s}) \rightarrow \mathrm{CaO}+\mathrm{CO}_{2}(\mathrm{~g})
$$

위와 같은 반응식에 따라 생석회가 생성되었다면 미생물 처 리 공정의 특성 상 생석회는 물과 만나 수화되면서 수산화칼 슘 $\left(\mathrm{Ca}(\mathrm{OH})_{2}\right)$ 이 될 것이다. 실험에 사용한 복합미생물 처리기 의 내부 온도는 약 $80{ }^{\circ} \mathrm{C}$ 이고 습도가 포화 상태에 이를 정도로 높기 때문에 생석회가 생성되자마자 수화반응이 동시에 일어 났을 것으로 예상된다. 그러나 XRD 분석 결과에서는 48 시간 처리한 시료나 72 시간 처리한 시료 모두에서 생석회나 수산 화칼슘이 관찰되지 않았다. 이 부분에 대해서는 앞으로 심도 있는 연구와 분석이 필요하다.

온도별 열처리 후의 중량감소에 대한 데이터를 보면 전체 적으로 48 시간 처리한 시료의 중량 감소량이 72 시간 처리한 시료의 중량 감소량보다 많다. 이것은 48 시간 처리한 시료 중의 유기물 함량이 많았기 때문으로 해석된다. 이 결과는 음식물류 폐기물의 유기성분을 분해하려면 최소한 48 시간 이 상 처리하는 시간이 필요함을 의미한다. 열분석에서도 이와 동일한 경향이 관찰되었으며 특기할 사실은 72 시간 처리한 시료에서 탄산칼슘이 생석회와 이산화탄소로 분해되는 현상 이 보다 분명하게 나타났다는 사실이다. 이것은 72 시간 처리 한 시료에서 유기물의 함량이 줄어들면서 상대적으로 탄산칼 슘의 양이 많아져 열분해 현상이 뚜렷하게 나타난 것으로 판 단된다. 


$$
\mathrm{CaCO}_{3}(\mathrm{~s})+2 \mathrm{HCl}(\mathrm{aq}) \rightarrow \mathrm{CaCl}_{2}(\mathrm{aq})+\mathrm{CO}_{2}(\mathrm{~g})+\mathrm{H}_{2} \mathrm{O}(\mathrm{l})
$$

또한 탄산칼슘이 염산과 반응하여 염화칼슘이 되는 반응식 (2)에서는 생성된 이산화탄소가 날아가면서 전체 중량이 $25 \%$ 감소한다. 따라서 시료 중의 탄산칼슘이 많을수록 염산과 반 응하여 감소하는 중량은 더 클 것으로 예상된다. Table5에서 보듯이 72 시간 처리한 시료의 감량이 더 크다는 사실은 상대 적으로 탄산칼슘의 양이 더 많았다는 것을 의미한다. 72 시간 처리한 시료에서 염산과 반응이 더 격렬했던 것도 탄산칼슘의 양이 상대적으로 많았기 때문으로 추정된다. 이것은 72 시간 처리한 시료의 중량 감소량이 이론적 예상 감소량인 $25 \%$ 에 근접하는 $27 \%$ 이었으나 48 시간 처리한 시료는 $12 \%$ 에 지나지 않았다는 사실로도 뒷받침된다.

\section{5. 결론}

공생관계에 있는 안정한 생태계를 이루는 복합미생물을 이 용하여 단시간 안에 음식물류 폐기물이 혼합된 폐패각의 소멸 이 가능하다는 사실이 확인되었으며 그 분해 기전은 새로운 현상으로서 보고된 바가 없다. 특히 $800{ }^{\circ} \mathrm{C}$ 이상의 고온에서 분해되는 것으로 알려진 탄산칼슘이 이보다 횔씬 낮은 온도인 $80{ }^{\circ} \mathrm{C}$ 에서 미생물에 의해 분해되었을 가능성은 열역학적으로 가능성이 매우 희박한 현상이다. 그러나 실험적으로 중량 감 소 현상이 확인되고 있으므로 실용적으로는 의미 있는 결과이 며 기전을 밝히기 위한 추가적인 연구가 필요하다.

\section{Acknowledgment}

본 연구는 미라클에코바이오(주)의 재정 지원에 의해 수행 되었습니다. 이에 감사드립니다.

\section{References}

1. Korea Agro-Fishers \& Food Trade Corporation, Agro-Fisheries \& Food Export Information, https://www.kati.net/product/ba sisInfo.do?lcdCode=MD181, June(2021).

2. C. W. Chung, Possibility to recycle domestic waste shells -with emphasis on oyster shells, J. Rec. Const. Resources, 11(1), 11-16(2016).

3. R. A. F. de Alvarenga, B. M. Galindro, C. de F. Helpa, S. R. Soares, The recycling of oyster shells: an environmental analysis using life cycle assessment, J. Environ. Manage., 106, 102-109(2012).

4. Chesapeake Bay Foundation, Save Oyster Shells in Maryland, Maryland Oyster Restoration Center, https://www.cbf.org/howwe-save-the-bay/programs-initiatives/maryland/oyster-restorati on/save-oyster-shells.html, July(2021).

5. E.-Y. Baek, W.-G. Lee, A study on the rational recycling of oyster-shell, J. Fish. Bus. Adm., 51(2), 71-87(2020).
6. S. B. Kim, Feasibility Study for Tongyeong City Oyster Shell Recycling Facility Installation Project and Master plan, Tongyeong city, Tongyeong, Repuclic of Korea(2013).

7. D. H. Hyun, A study on the feasibility and economic analysis of constructing an oyster shell recycling facility, Gyeongnam Regional Government Development Institute, Changwon, Repuclic of Korea(2019).

8. M-economynews, Gyeongnam suffers from oyster shells...is there any way to deal with it?, https://www.m-economynews. com/mobile/article.html?no=27338, June(2021).

9. Hansannews, Tongyeong City Council pays tribute to oyster shell culprits Principle...requires presentation of a plan, http://www.hansannews.com/news/articleView.html?idxno=64 291, June(2021).

10. The Hankyoreh, Gyeongnam local governments are very concerned about handling oyster shells during the boom year of farmed oysters, http://www.hani.co.kr/arti/area/yeong nam/914114.html, June(2021).

11. Hanryeotoday, A pilot project to eliminate odors from oyster shells using Effective Microorganisms, Tongyeong city, https://www.hanryeotoday.com/news/articleView.html?idxno= 51885, July(2021).

12. I. V. Vysotskii, A. A. Kornilova, Nuclear Transmutation of Stable and Radioactive isotopes in Biological systems, Pentagon Press, New Delhi, India, pp. 52-59(2010).

13. I. Shuryak, V. Y. Matrosova, E. K. Gaidamakova, R. Tkavc, O. Grichenko, P. Klimenkova, R. P. Volpe, M. J. Daly, Microbial cells can cooperate to resist high-level chronic ionizing radiation, PLoS One, 12(12), e0189261(2017).

14. W.-H. Chen, Y.-S. Chu, J.-L. Liu, J.-S. Chang, Thermal degradation of carbohydrates, proteins, lipids in microalgae alalyzed by evolutionary computation, Energy Convers. Manag., 160, 209-219(2018).

15. K. S. P. Karunadasa, C. H. Manoratne, H. M. T. G. A. Pitawala, R. M. G. Rajapakse, Thermal decomposition of calcium carbonate (calcite polymorph) as examined by in-situ high-temperature X-ray powder diffraction, J. Phys. Chem. Solids, 134, 21-28(2019)

16. J. S. Lee, M. S. Seo, D. S. Kim, Investigation on the material properties of waste oyster shell to use as an adsorbent for fluoride ion, Resour. Recycl., 16(3), 12-18(2007).

17. G. L. Lim, Y. C. Bak, Calcination and sulfation reactivity of oyster shell for dry, high-temperature desulfurization, Korean Chem. Eng. Res., 38(4), 541-549(2000).

18. S. H. Ha, M. K. Cha, K. J. Kim, S.-H. Kim, Y. Kim, Mineralogical and chemical characteristics of the oyster shells from Korea, J. Miner. Soc. Korea, 30(4), 149-159(2017).

\section{Declaration of Competing Interest}

The authors declare that they have no known competing financial interests or personal relationships that could have appeared to influence the work reported in this paper. 


\section{Authors and Contribution Statement}

\section{GunWoong Bahng}

Department of Mechanical Engineering, The State University of New York, Korea, Republic of Korea, Leading Professor, ORCiD (ㄹ 0000-0002-9223-7421: Conceptualization, Data curation, Data analysis, Visualization, Writing - original draft.

\section{Hyun Park}

Division of Biotechnology, Korea University, Republic of Korea, Professor, ORCID 두 0000-0002-8055-2010: Data curation, Data analysis.

\section{Myung Hee Suh}

Research Center, Miracle-Ecobio, Ltd., Republic of Korea, Head Manager, ORCID 시 0000-0002-3327-0934: Conceptualization, Data acquisition, Funding acquisition, Resources.

\section{Hany Hong}

Research Center, Miracle-Ecobio, Ltd., Republic of Korea, Principal Scientist, ORCID 시 0000-0002-7123-3325: Conceptualization, Methodology, Data acquisition, Resources. 